INTERNATIONAL JOURNAL OF RESEARCHES IN BIOSCIENCES, AGRICULTURE AND TECHNOLOGY

(C) VISHWASHANTI MULTIPURPOSE SOCIETY (Global Peace Multipurpose Society) R. No. MH-659/13(N)

\title{
www.ijrbat.in
}

\section{COMPARATIVE STUDIES ON THE WATER QUALITY STATUS OF NAGPUR RESERVOIRS.}

\begin{abstract}
Sanjay L Pal
Sevadal Mahila Mahavidyalaya and Research Academy, Nagpur (MS)

Corresponding Author Email : drsanjaypal24@gmail.com.

\section{ABSTRACT:}

Water is regarded as the elixir of life. At least on this planet earth, life cannot be imagined without water. Water is one of the abundantly available substances in nature. It is essential ingredient of animal and plant life. It is important to all living organisms, most ecological systems, human health, food production and economic development. Poor quality of water causes many problems to the humans, animals, plants etc. So the water must be tested physico-chemically as well as bacteriologically. Water samples were collected from the chosen sampling points of the four reservoirs and analyzed as per APHA standard methods. During the study it was found that maximum number of physical and chemical parameter were within the prescribed limit, as suggested by WHO(1971) and BIS(1991).The objective of the present study is to provide information on the physico-chemical characteristics of reservoir in order to discuss its suitability for human use. From the analysis report, it was found that the water analyzed from the four reservoirs was fit for irrigations, agricultural, industrial and domestic purpose.
\end{abstract}

Key words :- Reservoirs, ware quality index, Nagpur, Physico-chemical and Investigation, ecological studies, Comparative studies

\section{INTRODUCTION}

Water is one of the most important of all natural resources known on earth. It is important to all living organisms, ecological systems, human health, food production and economic development. The safety of drinking water is important for the health. The safety of drinking water is affected by various contaminants which included chemical and microbiological. Such contaminants cause serious health problems. Due to these contaminants quality of drinking water becomes poor. Sometimes such poor quality water causes many diseases in the humans, so that quality of water must be tested for both the chemical as well as for the microbial contaminants. The 5 major Application of water are Hydropower, Domestics uses, Irrigation, Industrial uses, Commercial uses. The major water quality parameters considered for the examination in this study are $\mathrm{pH}$, Odour, Colour, Taste, Temperature, Turbidity, Total Dissolved Solids (TDS), Dissolved oxygen (DO), Dissolved carbon dioxide, Metals and Metalloids, Total Hardness, Alkalinity.

\section{Sample Collection:}

Water sample was collected from four different reservoirs of Nagpur.
- Gandhisagar Reservoir.

- Sakkardara Reservoir.

- Ambazari Reservoir.

- Futala Reservoir.

\section{MATERIALS AND METHODS:}

The present study was carried out for four different water reservoirs, located in Nagpur city. In the present study the sampling was done during morning hours and all water samples were collected in the polyethylene bottles. For water sample collection, the closed bottle was dipped in the lake at the depth of 0.8 to $1.0 \mathrm{~m}$, and then a bottle was opened inside and was closed again to bring it out at the surface. The samples were collected from four different points and were mixed together to prepare an integrated sample. From the time of sample collection and to the time of actual analysis, many physical and chemical reactions would change the quality of water sample therefore to minimize this change the sample were preserved soon after the collection. The water samples were preserved by adding chemical preservatives and by lowering the temperature. The water temperature, odour, taste, total dissolved solids were analyzed immediately on the spot after the collection, whereas the analyses of remaining 
parameters were done in the laboratory. The study was carried for a period of four month (February 2016 to May 2016).The collected water samples were brought to the laboratory and relevant analysis was performed. $\mathrm{pH}$ was determined using $\mathrm{pH}$ meter, and similarly turbidity is measured by Turbidity meter. Alkalinity, Chloride, Calcium, Magnesium, Total Hardness, Dissolved oxygen, Dissolved carbon dioxide,Chemical Oxygen Demand(COD) Sulphate and Phosphate were determined by method according to table (Verma Pradeep et al, 2012).

\section{RESULTS AND DISCUSSION}

Physical parameters like temperature, odour and colour were agreeable but the taste of water is objectionable. Turbidity of the reservoir is ranging from 0.7 to $1.0 \mathrm{NTU}$. In Sakkardara reservoir, it has been observed that the turbidity (14NTU) is higher than the other water reservoirs. The $\mathrm{pH}$ value of all the reservoir has been observed in the range 6.9 to 8.2. This $\mathrm{pH}$ range is not at all harmful for the human use. Dissolved carbon dioxide and Dissolved oxygen were found to be 6.4 to $33 \mathrm{mg} / 1$ (average value of four reservoirs) respectively. Total Dissolved Solid (TDS) of water sample is within the prescribed limit. Total hardness and chloride is more in the water sample in all the reservoirs as compared to prescribed limit. Chemical Oxygen Demand (COD) and sulphate are also within the limit in all the water reservoirs. So, this water sample can be used for domestic, industrial and commercial but this water sample is unfit for drinking purposes. Water Temperature may be depending on the season, geographic location and sampling time. As water temperature increases, it makes it more difficult for aquatic life to get sufficient oxygen to meet its need. Thermal pollution can cause shifts in the community structure of aquatic organisms. Turbidity of lake ranges from 4 NTU to 11 NTU. Some are naturally highly turbid but human activities have increased the levels of suspended solids in many habitats. High value of suspended solid can lower the primary productivity of system by covering the algae and macrophytes, at times leading to almost their complete removal. The low oxygen level was recorded during summer mainly due to removal of free oxygen through respiration by bacteria and other animals as well as the oxygen demand for decomposition of organic matter. DO is the single most important gas for most aquatic organism. If the amount of free oxygen go below then $2.0 \mathrm{mg} / 1$ for few day in the lake containing aquatic organism it would lead the killing of most of the biota in the aquatic system. Higher value of free carbon dioxide generally coincided with minimum dissolved oxygen. Habited water is generally used by animals \& birds \& aquatic life. The disturbance in this biological system \& ecological system may affect health of animals \& birds \& aquatic life. After physicochemical analysis we found that the sample of habited water is free from pollution \& ecologically balanced.

Effectiveness of concentrated sulphuric acid, hot water and hot air oven treatment for breaking hardseededness was also reported in related crops by Borikar et al. (1985), Radhakrishnan et al. (1989), Rana and Nautiyal. (1989), Tomer and Maguire. (1989), Verma and Singh. (1989), Charjan and Tarar. (1991), Singh and Tomer. (1993) and Cherian et al. (2011).

\section{CONCLUSION :}

In the present study it has been observed that the result obtained of the water reservoirs are compared with ISI standards. It has been found that Sakkaradara and Futala Water Reservoir are polluted as compaired to other water reservoir. Therefore this reservoir can't be utilized for human uses, but Ambazari and Gandhisagar Water reservoir can be utilized for human uses. The entire water reservoir is generally used by animal's birds and aquatic life. The disturbance in this biological system and ecological system may affect health of animal birds and aquatic life. After Physico-Chemical Analysis it has been found that water sample of Ambazari and Gandhi sagar Water reservoir are less polluted and ecologically balanced as 
compaired to Sakkaradara and Futala Water Reservoirs.

\section{REFERENCES}

Basavaraja Simpi, S.M. Hiremath, KNS Murthy, K.N.Chandrashekarappa, Anil N Patel, E.T.Puttiah; Analysis of Water Quality Using Physico-Chemical Parameters Hosahalli Tank in Shimoga District, Karnataka, India; Global Journal of Science Frontier Research,11(3),2011.

Bhaven N. Tandel, Dr. JEM Macwan, and Chirag K. Soni, Assessment of Water Quality Index of Small Lake in South Gujarat Region, India.

Basavaraja Simpi, S.M. Hiremath, KNS Murthy, K.N.ChandrashekarappaAnil N Patel, E.T.Puttiah; Analysis of Water Quality Using Physico-Chemical Parameters Hosahalli Tank in Shimoga District, Karnataka, India; Global Journal of Science Frontier Research, 11(3); 2011.

H. A. Solanki, P. U. Verma and D. K. Chandawat, Evaluating The Water Quality of Malav Lake by Mean of Physico-chemical Analysis,944955,2011.

Hydrology project; Government of India \& Government of The Netherlands; Standard Analytical Procedures for Water Analysis May 1999.

Indian Standard Specifications for Drinking Water, IS: 10500, 1992

Jamie Bartram and Richard Ballance ,Physical And Chemical Analyses.

Jin Hur, Bo-Mi Lee, Tae-Hwan Lee and Dae-Hee Park ; Estimation of Biological Oxygen Demand and Chemical Oxygen Demand for Combined Sewer Systems Using Synchronous Fluorescence Spectra; Sensors 2010, 10, 2460-2471.

Kawther F. Abed and Suaad S. Alwakeel; Mineral and Microbial Contents of Bottled and Tap Water in Riyadh, Saudi Arabia; Middle-East Journal of Scientific Research, 2 (3-4): 151-156, 2007.
Krishna Vaidya and Mohini Gadhia; Evaluation of drinking water quality; African Journal of Pure and Applied Chemistry, 6(1):6- 9,10 2012.

M.M. Aldaya and M.R. Llamas;water footprinting analysis for the Guadiana River basin; November 2008 Value of Water Research Report Series No. 35.

Murhekar Gopalkrushna $\mathrm{H}$; International Journal of Research in Chemistry and Environment; Murhekar Gopalkrushna Int. J. Res. Chem. Environ. 1(2)2011(183-187).

O. A. Ojo, S. B. Bakare and A. O. Babatunde; Microbial and Chemical Analysis of Potable Water In Public Water Supply, Afr. J. Infect. Dis. 1(1): $30-35$.

O. Akoto; J. Adiyiah; Chemical analysis of drinking water from some communities in the Brong Ahafo region; Int. J. Environ. Sci. Tech., 4 (2): 211-214, 2007.

P. U. Verma, D. K. Chandawat and H. A. Solanki, Seasonal Variation In Physico-chemical and Phytoplankton Analysis of Kankaria Lake,842$854,2011$.

Rajini Kurup1, Roland Persaud, John Caesar, Vincent Raja; Microbiological and physiochemical analysis of drinking water in Georgetown, Guyana; Nature and Science, 2010;8(8).

Rudzka Kantoch $\mathrm{Z}$ and Weker H. Water in children's diet. Med Wieku Rozwoj.2000; 4:109 - 15.

S. D. Vediya and S. S. Patel, Cationic contamination in lake 'water situated South area at Ahmedabad, Gujarat, International Journal of Pharmacy \& Life Sciences, 2(2):2011.

S. D. Vediya, A.K. Shrivastva and R. P. Rathod, Pollution Status of Thaltej Lake, Prahladnagar Lake and Sola Lake Situated at Ahmedabad, Gujarat With Reference to Heavy Metals.

WHO's Drinking Water Standards, 1993

Boyd C.E. 1979: Water quality in warm water fishponds. Craft Master Printers, INC Opelika Alabama. 
Gwynfryn J. J. 2001: Freshwater Ecosystems- Structure and Response. Ecotoxicology and Environmental Safety 50: 107-113.

Vora A. B., Ahluwalia A.A.and Gupta R.Y. (1998). Study on water and soil, vegetation, zooplanktona and zoobenthos. In: Environmental Impact Assessment of Sardar Sarova Project on Nalsarovar Bird Sanctuary, Gujarat Ecological Education and Research (GEER) Foundation, Gandhinaga.

Sreenivasan, A. 1965. Limnology of tropical impoundments- III, Limnology and productivity of Amravathi reservoir, Madras. Hydrobiol 26 : 501-516.

Ahluwalia A. A.1999: Limnological Study of wetlands under Sardar Sarovar command area. Ph.D. Thesis. Gujarat University, Ahmedabad.

Gitanjali G. and Kumaresan A. 2006: Hydrochemical Quality of Courtallam water. Poll Res, 25(3): 583-588.

Walter K. D. 2002 : Freshwater Ecology Concepts and Environmental Applications, Academic press, pp: 288.

Renn C.E. (1968): A study of water quality: Lamotte chemical products company. Chestertown, Maryland pp: 46.
Mohanta B.K. and Patra A.K. 2000: Studies on the Water Quality Index of River Sanamachhakandana at Keonjhar Garh, Orrisa, Poll.Res. 19(3): 377-385.

Korium M.A. and Toufeek M.E.F. 2008 Studies of some physicochemical characteristics of old Aswan Dam reservoir and River nile water at Aswan. Egyptian. J. of aquat. Resear., 34: 149-167.

Govindan and Sundaresan B.B. 1979: Seasonal succession of algal flora in polluted region of Adyar river. Indian Journal of Environment and Health, 21, pp. 131-142.

Jana B.B.1973: Seasonal periodicity of plankton in fresh water ponds, West Bengasl, India. Journal of international Rev. Ges. Hydrobiology, 58:127-143.

Welch, P.S. 1952. Limonology, 2nd Ed., McGraw Hill Book Co., N.Y. pp: 536.

Vijayan V.S. 1991: Keoladeo National Park Ecology Study. Final report (19801990) BNHS, Bombay.

Gwynfryn J. J. 2001: Freshwater Ecosystems- Structure and Response. Ecotoxicology and Environmental Safety 50: 107-113.

\section{Table-1:Water quality parameters and methodology used.}

\begin{tabular}{|l|l|l|l|}
\hline S.No. & Water quality test & \multicolumn{1}{|c|}{ Description } & Instrument/Method. \\
\hline 1. & Temperature & $\begin{array}{l}\text { Temperature exerts a major influence on the } \\
\text { biological activities and growth }\end{array}$ & Thermometer \\
\hline 2. & Colour & $\begin{array}{l}\text { The term colour is used to mean the true } \\
\text { colour of water from which turbidity has } \\
\text { been removed. }\end{array}$ & $\begin{array}{l}\text { Platinum } \\
\text { visual cobalt } \\
\text { method }\end{array}$ \\
\hline 3. & Odour & $\begin{array}{l}\text { Odour is recognized as a quality factor } \\
\text { affecting acceptability of drinking water. }\end{array}$ & $\begin{array}{l}\text { Wide mouth glass } \\
\text { stoppered bottle }\end{array}$ \\
\hline 4. & Taste & $\begin{array}{l}\text { Taste of water ranging from agreeable to } \\
\text { disagreeable }\end{array}$ & By Tasting \\
\hline 5. & pH & $\begin{array}{l}\text { The major of acidity (hydronium ion,H+) in } \\
\text { the water. }\end{array}$ & pH meter \\
\hline 6. & Turbidity(NTU) & $\begin{array}{l}\text { Turbidity in water is the reduction of } \\
\text { transparency. }\end{array}$ & Turbidity meter \\
\hline 7. & TDS & $\begin{array}{l}\text { The measure of the amount of particulate } \\
\text { solids that are in the water }\end{array}$ & TDS meter \\
\hline 8. & Dissolved oxygen & $\begin{array}{l}\text { The amount of oxygen available in the } \\
\text { water. }\end{array}$ & $\begin{array}{l}\text { Titrimetric } \\
\text { (iodometric) }\end{array}$ \\
\hline 9. & Dissolved carbon dioxide & The amount of carbon dioxide in the water. & Titrimetric method \\
\hline 10. & Alkalinity & $\begin{array}{l}\text { Alkalinity of water is its quantitative } \\
\text { capacity to react with a strong acid to a } \\
\text { designated pH. }\end{array}$ & Titrimetric method \\
\hline 11. & Acidity & $\begin{array}{l}\text { Acidity of water is its quantitative capacity } \\
\text { Titrimetric method }\end{array}$ \\
\hline
\end{tabular}




\begin{tabular}{|l|l|l|l|}
\hline & & $\begin{array}{l}\text { to react with a strong base to a designated } \\
\mathrm{pH} .\end{array}$ & \\
\hline 12. & Chloride & Measurement of chloride amount in water & Titrimetric method \\
\hline 13. & $\begin{array}{l}\text { Chemical Oxygen Demand } \\
\text { (COD) }\end{array}$ & Amount of organic matter present in water & $\begin{array}{l}\text { Titrimetric method } \\
\text { (Iodometric) }\end{array}$ \\
\hline 14. & Magnesium & Measurment of Magnesium amount in water & Titrimetric method \\
\hline 15. & Calcium & Measurment of Magnesium amount in water & Titrimetric method \\
\hline 16. & Total hardness & $\begin{array}{l}\text { Measurment of calcium and magnesium in } \\
\text { water. }\end{array}$ & $\begin{array}{l}\text { Titrimetric method } \\
\text { (complexometric) }\end{array}$ \\
\hline 17. & Sulphate & Measurment of Sulphate in water & Spectrophotometer \\
\hline
\end{tabular}

Table- 2: Results of different water reservoirs.

\begin{tabular}{|c|c|c|c|c|c|}
\hline Sr.No. & Test & Gandhisagar & Sakkardara & Futala & Ambazari \\
\hline 1. & Temperature $\left({ }^{0} \mathrm{C}\right)$ & 29 & 28 & 30 & 28 \\
\hline 2. & Colour (Unit) & $<1$ & $<1$ & $<1$ & $<1$ \\
\hline 3. & Odour & Agreeable & Agreeable & Agreeable & Agreeable \\
\hline 4. & Taste & Agreeable & Agreeable & Agreeable & Agreeable \\
\hline 5. & $\mathrm{pH}$ & 6.9 & 8.2 & 7.5 & 7.8 \\
\hline 6. & Turbidity (NTU) & 0.8 & 14 & 0.9 & 0.7 \\
\hline 7. & TDS (ppm) & 350 & 365 & 356 & 364 \\
\hline 8. & Dissolved oxygen (ppm) & 6.1 & 6.2 & 6.3 & 6.4 \\
\hline 9. & Dissolved $\mathrm{CO}_{2}(\mathrm{ppm})$ & 38 & 36 & 40 & 38 \\
\hline 10. & Alkalinity (ppm) & 58 & 62 & 65 & 70 \\
\hline 11. & Acidity (ppm) & Nil & Nil & Nil & Nil \\
\hline 12. & Chloride (ppm) & 265 & 278 & 270 & 280 \\
\hline 13. & COD (ppm) & 80 & 75 & 78 & 85 \\
\hline 14. & Magnesium (ppm) & 25 & 23 & 22 & 26 \\
\hline 15. & Calcium (ppm) & 62 & 66 & 64 & 60 \\
\hline 16. & Total Hardness (ppm) & 220 & 217 & 205 & 210 \\
\hline 17. & Sulphate (ppm) & 28 & 30 & 24 & 26 \\
\hline
\end{tabular}

